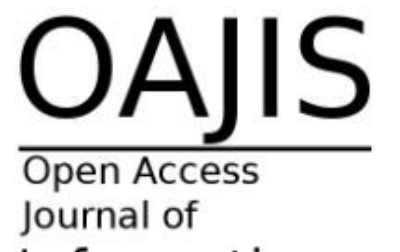

Information

Systems

is.its.ac.id/pubs/oajis/
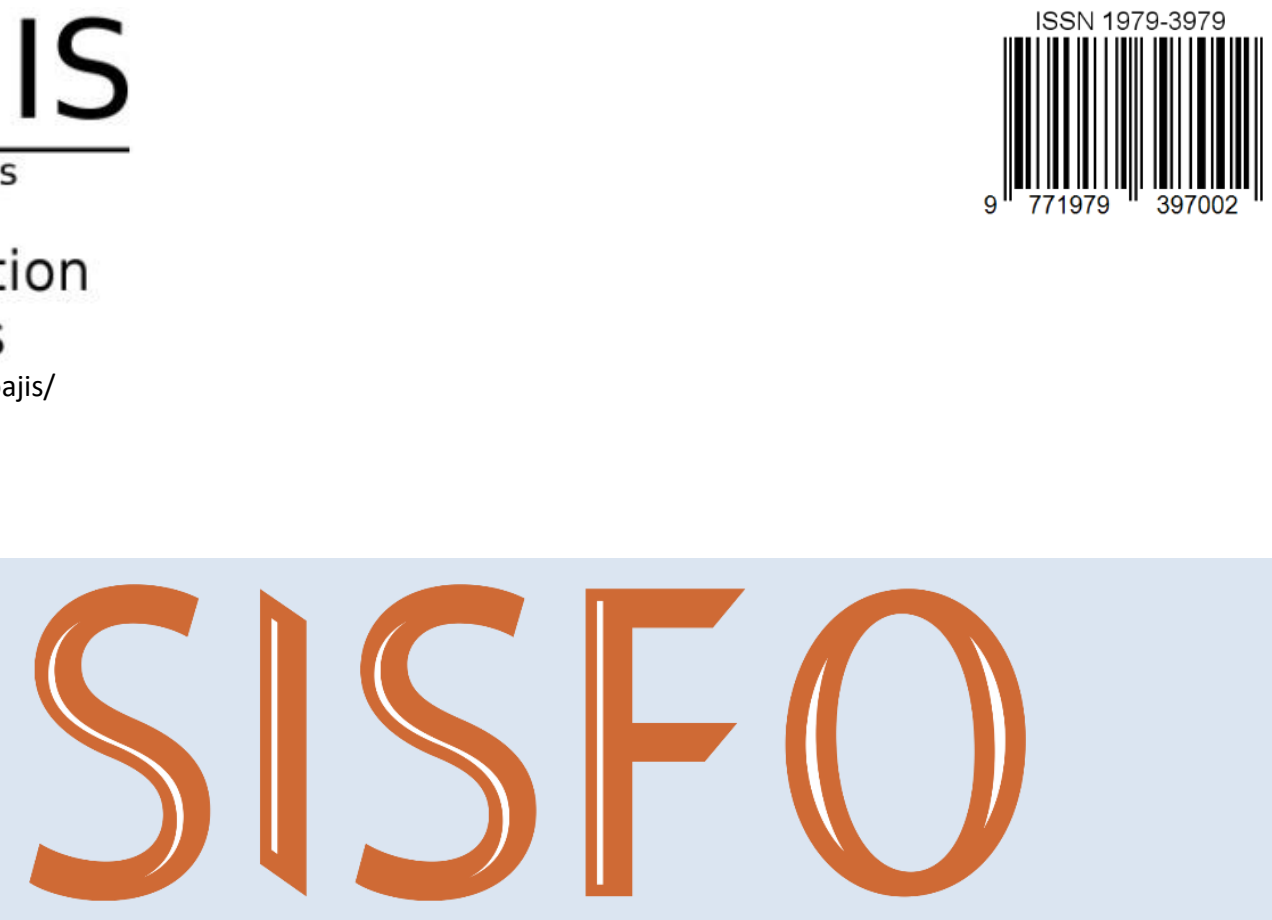

Inspirasi Profesional Sistem Informasi

\section{People}

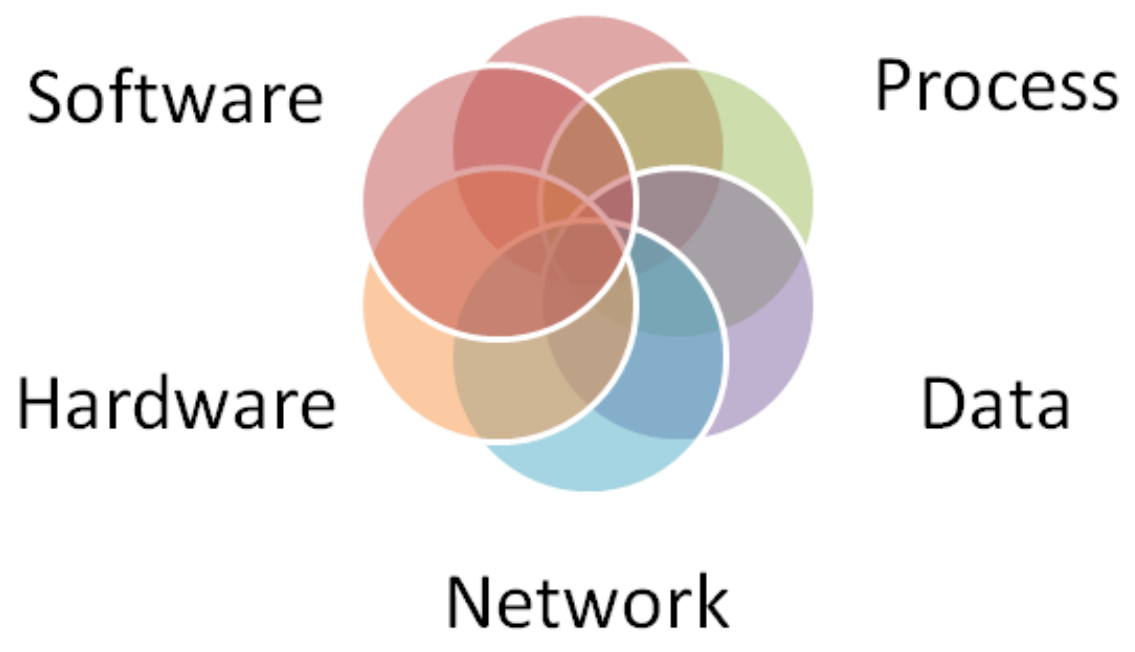


OAJIS

Journal of

Information

Systems

is.its.ac.id/pubs/oajis/

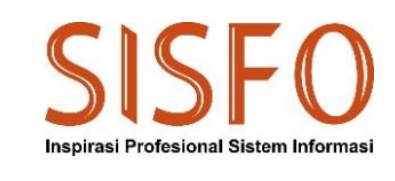

Jurnal Sisfo Vol. 08 No. 03 (2019) i-ii

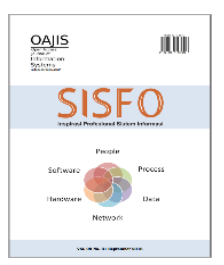

\section{Pimpinan Redaksi}

Faizal Mahananto

\section{Dewan Redaksi}

Eko Wahyu Tyas Darmaningrat

Amna Shifia Nisafani

Arif Wibisono

Rully Agus Hendrawan

\section{Tata Pelaksana Usaha}

\section{Achmad Syaiful Susanto}

Rini Ekowati

\section{Sekretariat}

Departemen Sistem Informasi - Fakultas Teknologi Informasi dan Komunikasi

Institut Teknologi Sepuluh Nopember (ITS) - Surabaya

Telp. 031-5999944 Fax. 031-5964965

Email: editor@jurnalsisfo.org

Website: http://jurnalsisfo.org

Jurnal SISFO juga dipublikasikan di Open Access Journal of Information Systems (OAJIS)

Website: http://is.its.ac.id/pubs/oajis/index.php 
OAJIS

Journal of

Information

Systems

is.its.ac.id/pubs/oajis/

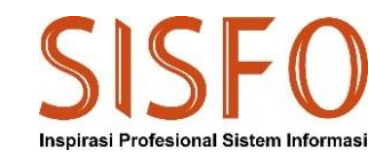

Jurnal Sisfo Vol. 08 No. 03 (2019) i-ii

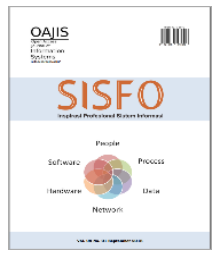

\section{Mitra Bestari}

Nur Aini Rakhmawati, Ph.D. (Institut Teknologi Sepuluh Nopember)

Rahadian Bisma, M.Kom. ITILF. (Universitas Negeri Surabaya)

Raras Tyasnurita, S.Kom, M.BA, Ph.D. (Institut Teknologi Sepuluh Nopember)

Satria Fadil Persada, S.Kom, M.BA, Ph.D (Institut Teknologi Sepuluh Nopember)

Sholiq, S.T, M.Kom, M.SA. (Institut Teknologi Sepuluh Nopember) 


\section{OAJIS \\ Open Access \\ Information \\ Systems \\ is.its.ac.id/pubs/oajis/}

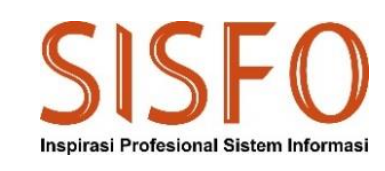

Jurnal Sisfo Vol. 08 No. 03 (2019) iii

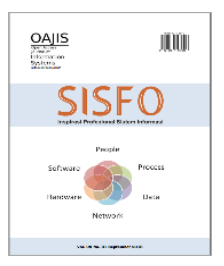

\section{Daftar Isi}

Identifikasi Karakteristik Teknik Elisitasi pada Rekayasa Kebutuhan Perangkat Lunak: Sebuah Review Sistematis

Endang Sulistiyani, Sasmi Hidayatul Yulianingtyas

Model Sistem Teleradiologi untuk Akses Pelayanan Kesehatan Rujukan

Romeo, Agus Sujadi

Integrasi Algoritma Blowfish untuk Pengamanan Data pada File MP3 dengan Steganografi LSB

Bonifacius Vicky Indriyono

Penyusunan Panduan Perawatan Software dan Hardware Pemerintah Kota Madiun Berdasarkan ISO/IEC 14764:2006 dan ITIL V3 2011

Umi Ridhoi, Anisah Herdiyanti, Tony Dwi Susanto.

Pengaruh Teknologi Informasi dalam Pertukaran Informasi dan Integrasi Rantai Pasok terhadap Performa Rantai Pasok

Achmad Wildan Nabila, Mahendrawathi ER 206 
Halaman ini sengaja dikosongkan 


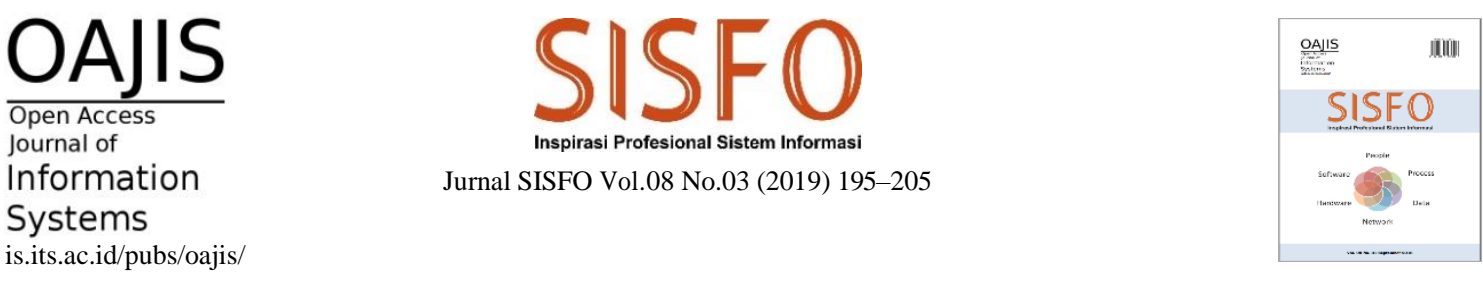

\title{
Penyusunan Panduan Perawatan Software dan Hardware Pemerintah Kota Madiun Berdasarkan ISO/IEC 14764:2006 dan ITIL V3 2011
}

\author{
Umi Ridhoi, Anisah Herdiyanti ${ }^{*}$, Tony Dwi Susanto \\ Departemen Sistem Informasi, Fakultas Teknologi Informasi dan Komunikasi, Institut Teknologi Sepuluh Nopember
}

\begin{abstract}
The Government of Madiun City has been engaging information technology (IT) with their daily routines. To ensure proper use of IT, software and hardware maintenance has been conducted regularly. Yet, the maintenance was done on an adhoc basis when a problem has arisen with software and hardware, and therefore the maintenance activities were not performed in a systematically manner. This situation created other problems, e.g. system breakdown, software bugs, hardware failure. This study focuses on the development of a guideline - that consists of procedures and formulir, to assist maintenance activities in the Government of Madiun City. The procedures were developed according to the IT governance framework that discusses service operation. Prior to the development of procedures, a gap analysis was identified. Then list of activities for software and hardware maintenance were organized within the respective procedures. The result from this study is proposing 7 (seven) procedures, and 12 formulir. This result can assist IT staff in the Government of Madium City when they conduct maintenance for software and hardware.
\end{abstract}

Keywords: Maintenance, Software, Hardware, Standard Operating Procedure, ISO/IEC 14764:2006, ITIL V3 2011

\begin{abstract}
Abstrak
Perawatan software dan hardware memiliki peran penting untuk memastikan bahwa teknologi informasi yang telah dikembangkan, dikelola dan dirawat sesuai fungsi dan tujuan organisasi. Bagi Pemerintahan Kota Madiun selaku pelaksana dalam pengelolaan software dan hardware belum pernah melakukan aktivitas perawatan secara berkelanjutan. Permasalahan terjadi yaitu proses perawatan dilakukan tidak berdasarkan prosedur, kesalahan pada software dan hardware, sehingga teknologi informasi tidak berjalan optimal. Penelitian ini melakukan standarisasi terhadap aktivitas perawatan dengan membangun panduan berisikan prosedur dan formulir perawatan software dan hardware. Daftar aktivitas didapatkan dari kerangka kerja Tata Kelola TI, yaitu: ISO/IEC 14764:2006 dan ITIL V3 2011. Selanjutnya analisis kesenjangan dilakukan dan dijadikan dasar dalam pembuatan prosedur. Hasil penyusunan panduan berisikan prosedur dan formulir adalah sebanyak 7 (tujuh) prosedur, dan 14 formulir untuk perawatan software dan hardware di lingkungan Pemerintah Kota Madiun.
\end{abstract}

Kata kunci: Perawatan, Software, Hardware, Standard Operating Procedure, ISO/IEC 14764:2006, ITIL V3 2011

(C) 2019 Jurnal SISFO.

Histori Artikel: Disubmit 11-02-2019; Direvisi 28-05-2019; Diterima 30-05-2019; Tersedia online 31-05-2019

*Corresponding Author

Email address: anisah@ is.its.ac.id (Anisah Herdiyanti)

https://doi.org/10.24089/j.sisfo.2019.05.004 


\section{Pendahuluan}

Maintenance (perawatan) merupakan suatu proses penting yang harus dilakukan setelah melakukan proses pengembangan suatu software serta hardware. Perawatan ini dilakukan untuk menjaga serta memperbaiki fasilitas sehingga sesuai dengan standar yang ada. Perawatan terhadap suatu sistem merupakan sebuah proses penting yang harus dilakukan untuk memastikan bahwa sistem berjalan dengan kondisi terbaik dan sesuai dengan tujuan [1]. Perawatan sistem yaitu suatu tindakan tepat dalam melakukan pencegahan ketika terdapat kesalahan dalam menjalankan suatu proses.

Proses perawatan membutuhkan suatu prosedur yang digunakan sebagai acuan bagi pihak dalam organisasi untuk memastikan bahwa proses perawatan yang dilakukan telah sesuai dengan standar yang tepat. Prosedur merupakan suatu hal yang sangat penting karena mempunyai beberapa manfaat, antara lain yaitu mencegah adanya kesalahan dan memudahkan dalam pengawasan, apabila terdapat kesalahan maka akan dilakukan tindakan perawatan berdasarkan fungsi serta tugasnya [2]. Maka dari itu, prosedur menjadi pedoman penting yang wajib dimiliki sebagai panduan ataupun acuan terhadap menjalankan setiap proses yang ada.

Dinkominfo Kota Madiun sebagai lembaga penyelenggara layanan sistem informasi terdapat pada ruang lingkup Pemerintahan Kota Madiun sedang membentuk e-government yang handal menuju smart city dengan melakukan integrasi tiga aplikasi yaitu $e$-budgeting, $e$-planning, dan e-kontrak [3]. Penerapan $e$ government pada Kota Madiun pasti dibutuhkan pengelolaan layanan sistem informasi yang tepat serta perawatan layanan secara benar. Supaya mampu menyediakan layanan seperti yang diinginkan oleh pengguna serta melakukan perawatan terhadap layanannya, Dinkominfo Kota Madiun harus memiliki standar dalam melakukan proses perawatan layanan untuk seluruh pengguna di Pemerintahan Kota Madiun. Sangat diperlukan panduan maintenance dalam memastikan bahwa permasalahan yang terjadi bisa ditangani dengan waktu yang sudah ditentukan.

Tetapi kenyataan yang saat ini terjadi bahwa proses perawatan infrastruktur software dan hardware yang dilakukan pada lingkup Pemerintahan Kota Madiun ini tidak mempunyai prosedur yang baku sebagai acuan untuk melakukan proses perawatan terhadap infrastruktur software dan hardware. Ketika pengguna mengalami permasalahan terhadap sistem informasi, lebih memilih untuk menghubungi Dinkominfo dan tidak adanya pencatatan untuk proses perawatan infrastruktur software dan hardware. Oleh karena itu, sangat diperlukan suatu prosedur yang terstandar sebagai panduan dalam melakukan proses perawatan sistem informasi yang terdapat pada tiga aplikasi tersebut sesuai dengan standar dan kontrol yang ada dan didokumentasikan dalam bentuk dokumen SOP dan formulir.

Dokumen SOP yang akan dibuat menggunakan metode analisis kesenjangan (gap analysis) terkait kondisi kekinian ketika melakukan proses perawatan ketiga aplikasi dengan kondisi ideal yang disesuaikan dengan standar ISO/IEC 14764:2006 Software Engineering-Software Life Cycle Process-Maintenance, sebagai kontrol ketika melaksanakan proses perawatan kepada sistem informasi yaitu pada modul dalam aplikasi tersebut [1]. Penambahan ITIL v3 untuk menjadi kontrol pelengkap terhadap IT Operation Management Function yang terdapat pada level Service Operation, yang tidak terdapat pada ISO/IEC 14764:2006 [4]. Pembuatan SOP serta formulir dan pemilihan penggunaan metode gap analysis ini berdasarkan beberapa penelitian yang telah dilakukan sebelumnya untuk menentukan prosedur dalam pembuatan SOP [5]. Sangat diharapkan bahwa dengan adanya SOP terkait perawatan infrastruktur software dan hardware ini bisa dijadikan sebagai acuan bagi Dinkominfo Kota Madiun dalam melakukan proses perawatan sistem informasi yang sesuai dengan standar. 


\section{Tinjauan Pustaka/Penelitian Sebelumnya}

Tinjauan pustaka digunakan sebagai dasar pengerjaan penelitian ini. Tinjauan pustaka dari penelitian adalah sebagai berikut.

\subsection{ISO/IEC 14764:2006}

Maintenance merupakan suatu standar ISO yang digunakan untuk melakukan proses perawatan perangkat lunak dengan memberikan panduan terkait pengelolaan (atau cara melakukan) proses perawatan perangkat lunak, seperti mengidentifikasi bagaimana proses perawatan perangkat lunak yang bisa dilakukan pada kondisi tertentu. Standar internasional ini juga menegaskan beberapa proses lain dalam perawatan perangkat lunak, seperti: kemampuan maintainability dari produk perangkat lunak, kebutuhan untuk model layanan dari perawatan perangkat lunak, dan kebutuhan untuk strategi serta perencanaan perawatan perangkat lunak [1]. Standar ini memberi kerangka kerja yang terencana dan spesifik terhadap bagaiman proses pemeliharaan perangkat lunak dilaksanakan, dievaluasi, dan disesuaikan dengan ruang lingkup pemeliharaan dan besarnya produk perangkat lunak tersebut. Dan standar ini memberikan kerangka, terminologi yang tepat serta proses untuk memungkinkan teknologi berupa aplikasi yang konsisten (alat, teknik dan metode) saat melalukan proses perawatan perangkat lunak. Standar ini memberi panduan dalam pemeliharaan perangkat lunak. Dasaran untuk proses pemeliharaan dan kegiatan berasal dari definisi ISO/IEC 12207 terkait definisi kegiatan dan tugas-tugas pemeliharaan perangkat lunak dan memberi persyaratan perencanaan pemeliharaan. Tetapi tidak membahas terkait pengoperasian perangkat lunak dan fungsi operasional seperti backup, recovery dan sistem administrasi yang biasa dilakukan oleh orang-orang yang mengoperasikan perangkat lunak.

\subsection{ITIL v3 2011}

ITIL v3 memiliki siklus hidup terhadap penerapan manajemen layanan teknologi informasi. Terdapat lima proses yang saling berkaitan satu sama lainnya. Peneliti membahas aktivitas pada bagian IT Operation Management Function pada Service Operation yang ada di kerangka kerja ITILv3 2011 terkait aktivitas monitoring and control beserta backup [5]. Diantara aktivitas yang terkait monitoring and control adalah mendefinisikan lingkungan dan objek yang akan diuji, menentukan tujuan, menentukan alat yang digunakan, menentukan tipe monitoring, menentukan tipe kontrol, melakukan monitoring pada lingkungan yang diuji, melakukan monitoring pada obyek yang diuji, melakukan tindakan perbaikan serta menyusun laporan hasil pemantauan. Sementara aktivitas backup diantaranya mengidentifikasi objek yang di-backup, mengidentifikasi frekuensi backup, menentukan tipe backup, menentukan lokasi penyimpanan data, menentukan metode transportasi backup, menentukan Recovery Point Objective, menentukan Recovery Time Objective, melakukan proses backup, melakukan pengujian serta menyimpan hasil backup.

\subsection{Tata Kelola Teknologi Informasi}

IT Governance adalah suatu komitmen, kesadaran dalam proses pengendalian manajemen organisasi terhadap sumber daya TI yang dibeli dengan harga mahal, mencakup dari sumber daya komputer seperti software, database, brainware hingga teknologi informasi serta jaringan internet. "Governance" yaitu turunan dari "government" memiliki artinya membuat kebijakan yang selaras dengan keinginan masyarakat [6]. Penggunaan "governance" terhadap teknologi informasi yaitu penerapan kebijakan TI dalam organisasi supaya pemakaian TI sesuai dengan tujuan organisasi tersebut. Pola pengelolaan yang dilakukan yaitu membangun kebijakan dan pengelolaan infrastruktur TI, penggunaan TI oleh end-user secara efisien, efektif serta aman dan proses IT Project Management yang efektif. 


\subsection{Hardware Maintenance}

Maintenance (perawatan) merupakan suatu kegiatan yang dilakukan untuk menjaga atau merawat sebuah benda atau perangkat agar bisa terus digunakan. Bertujuan untuk memperbaiki kesalahan (to correct), meningkatkan kinerja atau fungsionalitas (to improve), menyesuaikan dengan lingkungan (to adapt), atau untuk mencegah terjadinya kesalahan (to prevent) [1]. Manfaat perawatan hardware ini membuat organisasi akan lebih proaktif dalam menjalani perawatan terkait hardware. Dengan adanya aktivitas perawatan secara rutin terhadap hardware, maka pengguna dapat meminimalisir potensi permasalahan yang bisa muncul sewaktu-waktu. Peneliti menggunakan best practice dari Becta ICT Advice terkait Preventive Maintenance yang hanya berfokus kepada switch, router dan server secara harian dan bulanan. Namun juga menggunakan standar acuan ITILv3 terkait aktivitas monitoring and control.

Dapat disimpulkan bahwa SOP merupakan serangkaian panduan yang disusun secara sistematis mengenai proses, tugas, dan peran dari masing-masing individu maupun kelompok dalam menjalankan kegiatan sehari-hari di suatu organisasi. Namun, untuk analisis kesenjangan yang digunakan menggunakan analisis proses dalam melakukan pengelolaan layanan TI di pemerintahan Kota Madiun.

\section{Metodologi}

Metodologi penelitian merupakan acuan yang dibuat peneliti dalam mengerjakan penelitian agar menjadi terstruktur. Berikut ini merupakan gambaran dan uraian metodologi penelitian seperti terlihat pada Gambar 1. Metode penelitian seperti terlihat pada gambar tersebut terdiri dari 5 (lima) aktivitas utama, yaitu: pengumpulan data dan informasi, analisis kondisi kekinian dengan kondisi harapan, perancangan dan pembuatan dokumen SOP, verifikasi dan validasi serta penyusunan dokumen akhir.

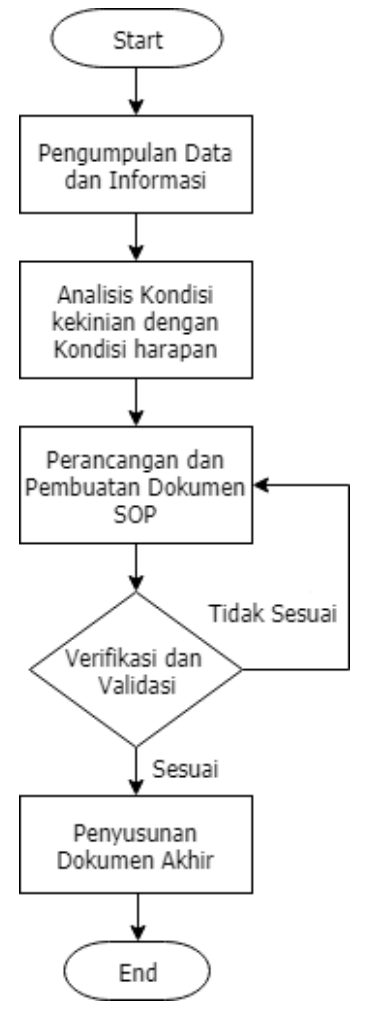

Gambar 1. Metodologi penelitian 


\section{Hasil dan Pembahasan}

Bagian ini menjelaskan hasil yang didapatkan dari penelitian ini, dan pembahasan secara keseluruhan yang didapatkan dari penelitian. Berikut ini merupakan hasil dan pembahasan sebagai berikut:

\subsection{Tahap Pengumpulan Data dan Informasi}

Merupakan tahapan dimana penulis melakukan pengumpulan data dan informasi yang akan digunakan untuk bahan analisis dan penyusunan dokumen SOP dan formulir. Pengumpulan data dan informasi berdasarkan kondisi kekinian dilakukan dengan menggunakan metode wawancara, observasi yang dilakukan secara langung dan studi dokumen.

1) Wawancara

Wawancara dilakukan dengan mengajukan pertanyaan dari daftar interview protocol untuk mengetahui kondisi kekinian dan kondisi yang diharapkan pada organisasi. Wawancara dilakukan secara langsung kepada pihak narasumber terkait dengan data dan informasi yang dibutuhkan oleh peneliti. Narasumber penelitian mencakup: Kasi Layanan Aplikasi dan Tata Kelola Pemerintahan Elektronik, dan 2 orang staff Kasi Layanan.

2) Observasi

Observasi dilakukan dengan mengamati kondisi dan proses perawatan software dan hardware secara langsung untuk mendapatkan informasi mengenai kondisi nyata yang terjadi. Observasi dilakukan terhadap proses perawatan software secara langsung menemui tim Helpdesk Pemerintah Kota Madiun.

3) Studi dokumen

Metode ini dilakukan oleh peneliti untuk menganalisis dokumen SOP yang dimiliki oleh Dinkominfo Kota Madiun kemudian dijadikan sebagai masukan dalam pembuatan SOP untuk pembuatan dokumen SOP terkait perawatan software dan hardware.

\subsection{Hasil Analisis Kesenjangan Kondisi Kekinian dan Kondisi Ideal}

Analisis kesenjangan dilakukan dengan cara menganalisis kondisi kekinian berdasarkan aktivitas yang terdapat didalam standar acuan dan membandingkannya dengan kondisi ideal menurut ISO/IEC 14764:2006 dan ITIL v3 2011[7]. Selanjutnya dilakukan pemetaan terkait kondisi kekinian dan kondisi ideal untuk memudahkan dalam mengetahui kesenjangan yang terjadi, sehingga analisis kesenjangan ini digunakan untuk mengetahui adanya ketidak sesuaian antara kondisi kekinian dengan kondisi ideal menurut standar acuan [8]. Berikut ini merupakan pemetaan hasil analisis kesenjangan dari semua proses dengan melakukan perbandingan antara kondisi kekinian dengan kondisi ideal menurut standar acuan ISO/IEC 14764:2006 dan ITIL v3 2011 seperti terlihat pada Tabel 1. Berdasarkan analisis tersebut didapatkan kesimpulan bahwa aktivitas perawatan belum dilakukan secara terstandar sesuai dengan kerangka kerja Tata Kelola TI yang diacu pada penelitian ini.

Tabel 1. Hasil analisis kesenjangan

\begin{tabular}{lll}
\hline Proses & \multicolumn{1}{c}{ Kesenjangan } & \multicolumn{1}{c}{ Usulan } \\
\hline & $\begin{array}{l}\text { Klien tidak melaporkan permintaan perbaikan/perawatan ke } \\
\text { Service Desk }\end{array}$ & $\begin{array}{l}\text { Membuat prosedur tertulis yang } \\
\text { menjelaskan aktivitas sesuai standar } \\
\text { acuan best practice } \text { ISO/IEC } \\
\text { Process Implementation }\end{array}$ \\
& $\begin{array}{l}\text { Tidak adanya prosedur tertulis yang jelas sesuai dengan } \\
\text { standar }\end{array}$ & \\
\hline
\end{tabular}




\begin{tabular}{|c|c|c|}
\hline Proses & Kesenjangan & Usulan \\
\hline \multirow{7}{*}{$\begin{array}{l}\text { Problem and Modification } \\
\text { Analysis }\end{array}$} & $\begin{array}{l}\text { Staf hanya melakukan proses analisis secara singkat terkait } \\
\text { laporan permintaan perbaikan/modifikasi yang diterima oleh }\end{array}$ & \multirow{7}{*}{$\begin{array}{l}\text { Membuat prosedur tertulis yang } \\
\text { menjelaskan aktivitas sesuai standar } \\
\text { acuan best practice ISO/IEC } \\
\text { 14762:2006 }\end{array}$} \\
\hline & klien, tidak detail & \\
\hline & Staf tidak selalu melakukan koordinasi dengan & \\
\hline & klien terkait aktivitas perbaikan/perawatan & \\
\hline & $\begin{array}{l}\text { yang dilakukan, hanya diperlukan setelah proses } \\
\text { perawatan/perbaikan dilakukan }\end{array}$ & \\
\hline & $\begin{array}{l}\text { Tidak ada proses dokumentasi dalam melakukan analisis } \\
\text { perawatan software }\end{array}$ & \\
\hline & $\begin{array}{l}\text { Tidak adanya prosedur tertulis yang jelas sesuai dengan } \\
\text { standar }\end{array}$ & \\
\hline \multirow{2}{*}{$\begin{array}{l}\text { Modification } \\
\text { Implementation }\end{array}$} & $\begin{array}{l}\text { Tidak adanya proses dokumentasi dalam melakukan } \\
\text { implementasi dan pengujian dari hasil perawatan/perbaikan } \\
\text { terhadap software }\end{array}$ & \multirow{2}{*}{$\begin{array}{l}\text { Membuat prosedur tertulis yang } \\
\text { menjelaskan aktivitas sesuai standar } \\
\text { acuan best practice ISO/IEC } \\
\text { 14762:2006 }\end{array}$} \\
\hline & $\begin{array}{l}\text { Tidak adanya prosedur tertulis yang jelas sesuai dengan } \\
\text { standar }\end{array}$ & \\
\hline
\end{tabular}

Staf tidak memiliki review dan evaluasi terkait pelaksanaan dan hasil dari aktivitas perbaikan/perawatan pada software yang telah dilakukan

Maintenance

Review/Acceptance
Staf mengakhiri aktivitas perbaikan/perawatan hanya dengan melakukan konfirmasi ke klien atau Service Desk untuk mengakhiri e-tiket permintaan.
Membuat prosedur tertulis yang menjelaskan aktivitas sesuai standar acuan best practice ISO/IEC 14762:2006

Tidak adanya prosedur tertulis yang jelas sesuai dengan standar

Tidak adanya dokumentasi dalam proses evaluasi

Tidak adanya prosedur tertulis yang jelas

sesuai standar

Migration

Tidak adanya dokumentasi dalam proses migrasi

Membuat prosedur tertulis yang menjelaskan aktivitas sesuai standar acuan best practice ISO/IEC

Tidak adanya prosedur tertulis yang jelas sesuai dengan standar

14762:2006 tambahan aktivitas

Migration dan Retirement

Retirement

Tidak adanya dokumentasi dalam proses

Retirement 


\begin{tabular}{|c|c|c|}
\hline Proses & Kesenjangan & Usulan \\
\hline \multirow{4}{*}{ Backup } & $\begin{array}{l}\text { Alur proses yang belum dilakukan seperti Recovery Point } \\
\text { Objective dan Recovery Time Objective sebelum proses } \\
\text { backup dimulai }\end{array}$ & \multirow{4}{*}{$\begin{array}{l}\text { Membuat prosedur tertulis yang } \\
\text { menjelaskan urutan aktivitas backup } \\
\text { dan monitoring yang memenuhi } \\
\text { standar acuan aktivitas di kerangka } \\
\text { kerja ITILv3 }\end{array}$} \\
\hline & Formulir backup belum sesuai dengan standar & \\
\hline & Tidak adanya prosedur tertulis yang jelas sesuai standar & \\
\hline & $\begin{array}{l}\text { Aktivitas monitoring terjadi saat terdapat permasalahan pada } \\
\text { software }\end{array}$ & \\
\hline \multirow{2}{*}{ Monitoring and Contr } & $\begin{array}{l}\text { Tidak adanya penyusunan laporan hasil pemantauan dan } \\
\text { tindakan yang akan dilakukan dari hasil tersebut }\end{array}$ & \\
\hline & $\begin{array}{l}\text { Tidak adanya prosedur tertulis yang jelas sesuai dengan } \\
\text { standar }\end{array}$ & \\
\hline \multirow{3}{*}{ Perawatan Hardware } & $\begin{array}{l}\text { Aktivitas perawatan hardware terjadi saat terdapat } \\
\text { permasalahan pada hardware }\end{array}$ & \multirow{3}{*}{$\begin{array}{l}\text { Membuat prosedur tertulis yang } \\
\text { menjelaskan urutan aktivitas } \\
\text { perawatan hardware berdasarkan } \\
\text { standar acuan Becta ICT Advice - } \\
\text { Preventive Maintenance }\end{array}$} \\
\hline & $\begin{array}{l}\text { Tidak adanya penyusunan laporan hasil perawatan hardware } \\
\text { dan tindakan yang akan dilakukan dari hasil tersebut }\end{array}$ & \\
\hline & $\begin{array}{l}\text { Tidak adanya prosedur tertulis yang jelas sesuai dengan } \\
\text { standar }\end{array}$ & \\
\hline
\end{tabular}

\subsection{Penyusunan Standard Operating Procedure}

Penyusunan standard operating procedure (SOP) mengacu pada struktur yang diatur dalam Peraturan Menteri Pendayagunaan Aparatur Negara dan Reformasi Birokrasi Republik Indonesia Nomor 35 tahun 2012. Dalam penyusunan format SOP didasarkan pada tujuan pembuatan SOP serta tidak adanya format baku dalam penyusunan format SOP[9]. Sehingga apabila terdapat perbedaan tujuan pembuatan SOP, maka format SOP akan ikut berbeda juga. Setelah dokumen SOP selesai dibuat maka akan dilakukan tahap verfifkasi dan tahap validasi untuk mengetahui apakah dokumen SOP sesuai dengan kriteria yang dibutuhkan oleh organisasi. Berikut ini merupakan penyusunan SOP dan formulir yang dihasilkan dengan menggunakan kode untuk setiap SOP dan formulir yang ditunjukkan pada Tabel 2.

Tabel 2. Pemetaan SOP dan formulir

\begin{tabular}{cccc}
\hline No SOP & Nama SOP & No Formulir & Nama Formulir \\
\hline SOP- DINKOMINFO-005 & SOP Perbaikan Aplikasi & FRM-DINKOMINFO-009 & Formulir Pengujian dan Evaluasi \\
\hline SOP- DINKOMINFO-006 & SOP Migrasi Aplikasi & FRM-DINKOMINFO-010 & Formulir Laporan Perbaikan Aplikasi \\
\hline
\end{tabular}




\begin{tabular}{|c|c|c|c|}
\hline No SOP & Nama SOP & No Formulir & Nama Formulir \\
\hline & & FRM-DINKOMINFO-013 & Formulir Spesifikasi Kebutuhan \\
\hline & & FRM-DINKOMINFO-009 & Formulir Pengujian dan Evaluasi \\
\hline & & FRM-DINKOMINFO-012 & Formulir Laporan Migrasi Aplikasi \\
\hline \multirow{4}{*}{ SOP- DINKOMINFO-007 } & \multirow{4}{*}{ SOP Pemberhentian Aplikasi } & FRM-DINKOMINFO-011 & Formulir Berita Acara Diskusi \\
\hline & & FRM-DINKOMINFO-013 & Formulir Spesifikasi Kebutuhan \\
\hline & & FRM-DINKOMINFO-009 & Formulir Pengujian dan Evaluasi \\
\hline & & FRM-DINKOMINFO-014 & Formulir Laporan Pemberhentian Aplikasi \\
\hline SOP- DINKOMINFO-008 & $\begin{array}{l}\text { SOP Backup Database dan } \\
\text { Aplikasi }\end{array}$ & FRM-DINKOMINFO-015 & $\begin{array}{l}\text { Formulir Laporan Backup Database dan Sistem } \\
\text { Informasi }\end{array}$ \\
\hline \multirow{2}{*}{ SOP- DINKOMINFO-009 } & \multirow{2}{*}{ SOP Pemantauan Aplikasi } & FRM-DINKOMINFO-009 & Formulir Pengujian dan Evaluasi \\
\hline & & FRM-DINKOMINFO-016 & Formulir Laporan Pemantauan Aplikasi \\
\hline SOP- DINKOMINFO-010 & SOP Infrastruktur TI & FRM-DINKOMINFO-017 & Formulir Perawatan Infrastruktur TI \\
\hline SOP- DINKOMINFO-017 & $\begin{array}{l}\text { SOP Permintaan } \\
\text { Perawatan Aplikasi }\end{array}$ & FRM-DINKOMINFO-034 & Formulir Permintaan Perawatan Aplikasi \\
\hline
\end{tabular}

\subsection{Pembuatan Dokumen SOP}

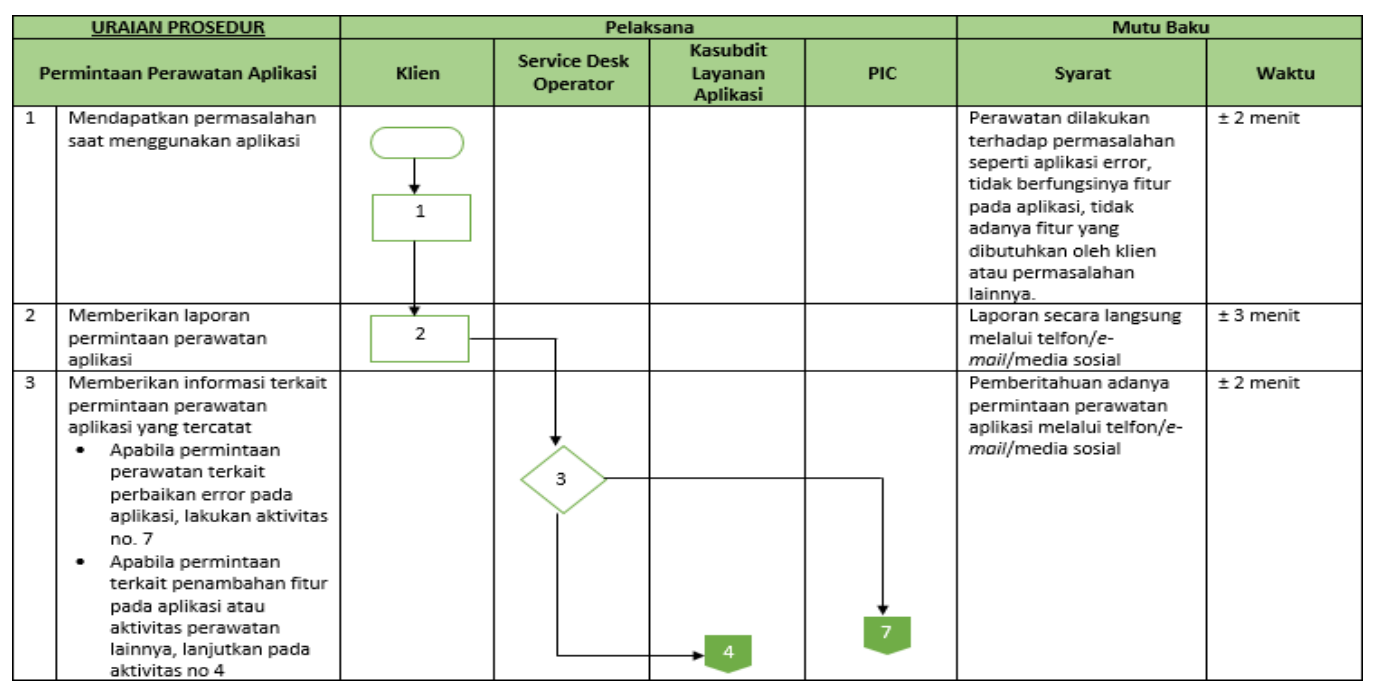




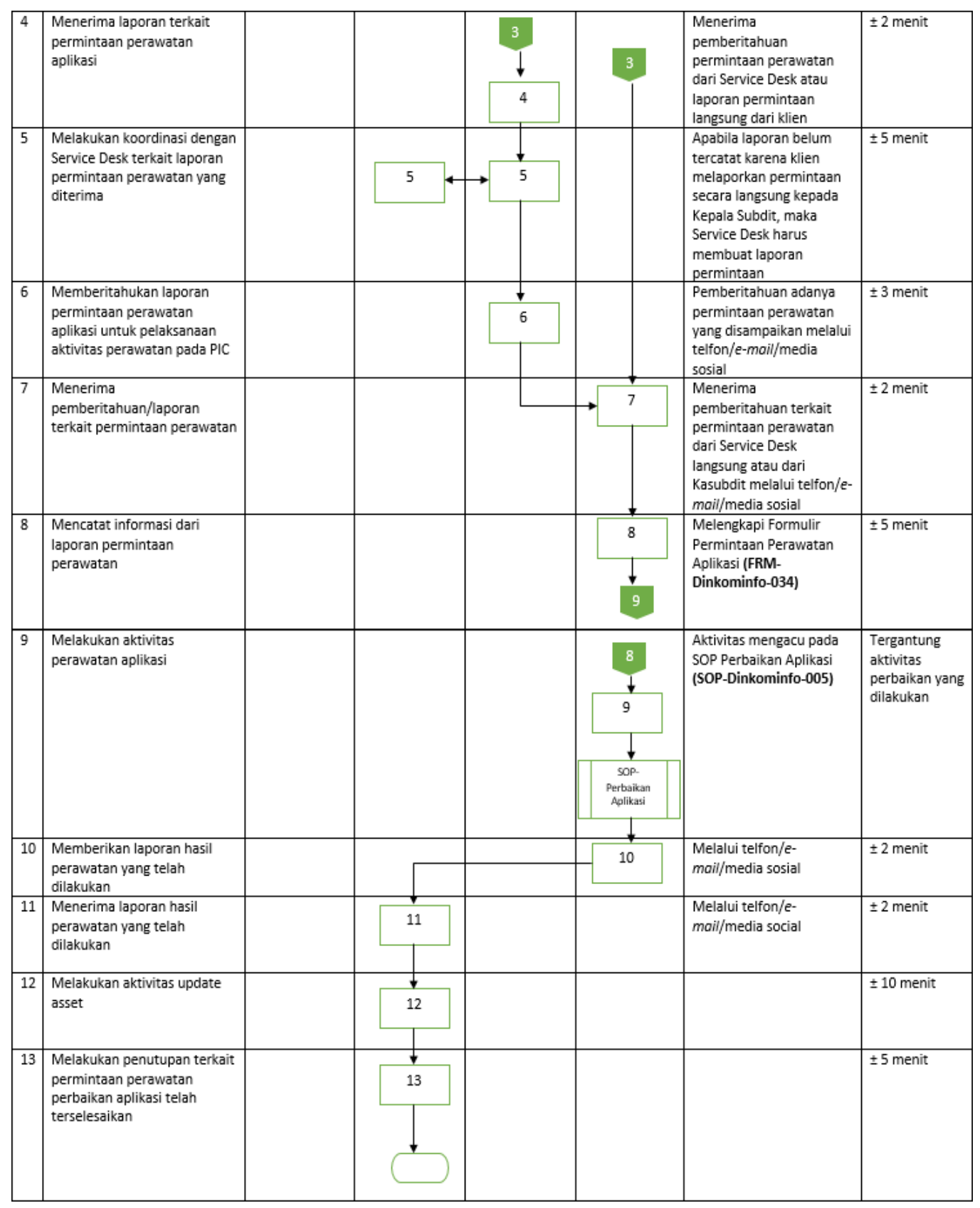

Gambar 2. SOP permintaan perawatan aplikasi

Pada bagian ini akan dipaparkan penjelasan mengenai salah satu prosedur yang tertera dalam SOP incident management. Dalam melakukan penyusunan SOP incident management peneliti menggunakan panduan SOP menurut Peraturan Menteri Pendayagunaan Aparatur Negara dan Reformasi Birokrasi Republik Indonesia Nomor 35 Tahun 2012 [10] tentang Pedoman Penyusunan Standar Operasional Prosedur Administrasi Pemerintahan, yang merupakan revisi dari peraturan sebelumnya Permenpan No. 52 Tahun 2011 [11]. Gambar 2 menunjukkan prosedur permintaan perawatan aplikasi sesuai dengan struktur yang diatur dalam peraturan menteri tersebut. Prosedur ini terkait dengan formulir permintaan perawatan aplikasi (terhubung dengan Madiun Service Desk [12]). 


\section{Kesimpulan}

Pada bagian ini dipaparkan hasil simpulan dari penelitian yang dilakukan. Selain itu dipaparkan saran yang bermanfaat untuk penelitian di masa yang akan datang.

\subsection{Simpulan}

Berdasarkan hasil analisis kesenjangan, didapatkan simpulan bahwa aktivitas perawatan yang dilakukan belum terstandar sesuai dengan kerangka kerja Tata Kelola TI, yaitu: ISO/IEC 14764:2006 dan ITILv3 2011. Analisis tersebut dijadikan dasar penyusunan 7 (tujuh) prosedur, yaitu prosedur permintaan perwatan aplikasi, prosedur perbaikan aplikasi, prosedur migrasi aplikasi, prosedur pemberhentian aplikasi, prosedur backup database aplikasi, prosedur pemantauan aplikasi dan prosedur perawatan infrastruktur TI yang sudah tersistem pada aplikasi Madiun Service Desk. Pada setiap prosedur memiliki 14 (empat belas) formulir yang mendukung pelaksanaan prosedur yaitu formulir pemenuhan permintaan, formulir pengujian dan evaluasi, formulir perbaikan aplikasi, formulir berita acara diskusi, formulir migrasi aplikasi, formulir spesifikasi kebutuhan, formulir pemberhentian aplikasi, formulir laporan backup database dan sistem informasi, formulir pemantauan aplikasi, formulir laporan perawatan infrastruktur TI, formulir laporan perawatan infrastruktur TI (server) harian, formulir laporan perawatan infrastruktur TI (server) bulanan, formulir laporan perawatan infrastruktur TI (switch) dan formulir laporan perawatan infrastruktur TI (router).

\subsection{Saran}

Saran yang diberikan oleh peneliti terkait dengan penelitian tugas akhir ini, antara lain:

1) Penelitian ini tidak melakukan aktivitas pemantauan pada jaringan untuk SOP Perawatan Infrastruktur TI

2) Penelitian ini memiliki batasan yang hanya berfokus pada proses perbaikan aplikasi, migrasi aplikasi, pemberhentian aplikasi, backup database aplikasi, pemantauan aplikasi, perawatan infrastruktur TI yang berfokus hanya pada switch, router dan server.

3) Penelitian ini tidak melakukan pemantauan terkait penggunaan SOP pada kegiatan sehari-hari sehingga untuk penelitian selanjutnya bisa melakukan penelitian terkait kinerja dan evaluasi terhadap penerapan SOP.

\section{Daftar Rujukan}

[1] P. Croll, T. Pigoski, and J. W. Moore, ISO/IEC 14764-2006: Software Engineering - Software Life Cycle Processes Maintenance, vol. 2006. 2006.

[2] Atmoko. Tjipto, "Standar Operasional Prosedur (SOP) dan Akuntabilitas Kinerja Instansi Pemerintah," 2008.

[3] D. Admin, "Integrasikan E-Budgetting, E-Planning dan E-Kontrak, Kota Madiun Menuju Smart City - Pemerintah Kota Madiun." 2018.

[4] itSMF UK, “An Introductory Overview of ITIL 2011 Edition,” vol. 5, no. 5, pp. 608-608, 2012.

[5] B. C. Hidayanto, A. N. Ragiltya, A. Herdiyanti, "Pembuatan Standard Operating Procedure Perawatan Sistem Informasi Manajemen Institut Teknologi Sepuluh Nopember,” Jurnal SISFO, vol.7, no.1, 2017.

[6] I. P. A. Swastika and I. G. L. A. R. Putra, "Audit Sistem Informasi dan Tata Kelola Teknologi Informasi : Implemantasi dan Studi Kasus.” p. 224, 2016.

[7] OGC, "ITIL v3 Service Operation, Office of Government Commerce," 2010.

[8] A.F. Rizky, A. Herdiyanti, T.D. Susanto, "Pembuatan Prosedur Operasional Standar Pengelolaan Insiden pada Government Resources Management Systems Kota Surabaya Berdasarkan ITIL V3,” Jurnal SISFO, vol. 6, no.2, 2017.

[9] "Peraturan Menteri, 'Pedoman Penyusunan Standar Operasional Prosedur Administrasi Pemerintah,' Kementerian Pendayagunaan Aparatur Negara dan Reformasi Birokrasi RI,” 2012. [Online]. Available: http://www.kopertis3.or.id/html/wpcontent/uploads/2011/04/permenpan2012 035.pdf. [Accessed: 29-Mar-2018].

[10] A. Herdiyanti, A.C. Puspitaningrum, H.M. Astuti, U. L. Yuhana, "Pembuatan Standard Operating Procedure Pengembangan Sistem Informasi Manajemen: Studi Kasus DPTSI ITS,” Jurnal SISFO, vol. 8, no.1, 2018. 
[11] M. Farid, T.D. Susanto, A.S. Nisafani, "Pembuatan SOP Menurut PERMENPAN No.52 Tahun 2011 dengan Best Practice COBIT 5 dan ITIL V3," Seminar Nasional Sistem Informasi Indonesia, 2013.

[12] Z. Effendi, A. Herdiyanti, T.D. Susanto, "Pembuatan Prosedur dan Formulir Service Desk Pemerintahan Kota Madiun Berdasarkan ITIL V3,” Jurnal SISFO, vol. 8, no.2, 2019. 
